\title{
Another inconvenient truth
}

\section{In Europe, no one apparently wants to listen if you have good news about genetically modified organisms (GMOs).}

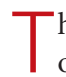
here have been two distinct calls for complete bans on the release of GMOs in France and Italy in recent weeks. Predictably, both are motivated strictly by political ambitions. Less predictably and of much greater concern, both have complete disregard for any of the data that surround the GMO issue.

At the end of October, French president Nicolas Sarkozy announced that, in accordance with 'the precautionary principle', no more approvals would be granted in France for the cultivation of genetically modified Bacillus thuringiensis $(B t)$ toxin maize until an expert group — which at that time had not been formed-had assessed the benefits and risks. The announcement came at the end of a broadranging discussion forum on the future of French environmental policy.

The interpretation of the move is that GMOs are to be the sacrificial lamb that allows Sarkozy to demonstrate to the green lobbies that he is not uniformly uncritical of technological solutions in the environmental arena. This is clearly playing politics as the ban is certain to be declared illegal by the European Commission. Agricultural Commissioner Mariann Fischer Boel has already told Paris that the ban on products that have been approved by the European Union (EU) violates the EU Treaty. National exceptions to EU approvals can be made, but they must be supported by new data on risks to human health or the environment. Neither Sarkozy nor anyone among his administration or advisory team has suggested that they have a single iota of new data.

There were new data from Italy in mid-November but, oddly, they were largely ignored. Usually, the slightest evidence derived from potatoes loaded with toxins or caterpillars force-fed in sandwich boxes can be apparently accorded significant media merit if there is a sniff of genetic modification around the protocol. Similarly, highly predictable observations on gene transmission are heralded as surprising and deep if the DNA involved has been anywhere near a ligase in vitro in its past 1,000 replications.

The reason the new Italian data-from the only field trial of $B t$ maize in Italy since 2000-was ignored is simple: it showed GMOs in a positive light. The trial was performed in 2005 as part of what was supposed to be a broad popular overview of GMOs in Italy. The National Research Institute for Food and Nutrition (INRAN) had organized and funded a set of activities around the GM food and crop issue. In addition to this trial, it funded educational activities and opinion surveys. The outcomes were to be presented at a public meeting in 2006, but the full field trial data were never released. When it became clear that neither INRAN nor the Ministry of Agriculture was going to publish the trial data, a small band of determined plant biotech researchers held a press conference on November 13.

The results of the trial were spectacular. It involved four plots of 3,600 square meters, one for each of two different GM varieties (both featuring the Monsanto MON810 event) and their isogenic non-GM equivalents. The trial was planned and conducted not by a corporate villain but by a respected agronomist from the University of Milan, Tomasso Maggiore. He showed that under field conditions recombinant maize expressing $B t$ toxin can help maintain yield levels that are $28-43 \%$ higher than those of isogenic non-GM varieties. The results are almost certainly atypical because climatic and other conditions during 2005 resulted in a particularly good year for the European corn borer and a particularly bad year for Italian growers of conventional maize. In a more typical year, yield losses due to the insect might have been only $10-15 \%$ of the crop mass.

Productivity benefits aside, MON810 corn also outperformed conventional corn in terms of the levels of fumonisin, toxins that are produced by fungi able to infect plants through lesions caused by the corn borer. MON810 corn contained 60 or fewer parts per billion of fumonisin, whereas non-GM varieties contained over 6,000 parts per billion, a level unsuitable for human consumption under Italian and European law.

If it had been the MON810 varieties that contained high levels of fungal toxins, interest of the politicians, the media and the general public in the data would likely have been intense. But the response to these inconveniently positive field trial data was unreceptive at best.

The press conference of November 13 followed several months of intensive campaigning by a coalition of over 30 groups claiming to represent over 11 million Italians opposed to GM foods. The 'Italy/ Europe Free of GMO' coalition, which encompassed several Italian farming unions, consumer associations and environmental groups, such as Greenpeace and the Worldwide Fund for Nature, had organized nearly 2,000 separate anti-GM events and in a mock referendum collected three million signatures calling for a complete ban on all GM foods in Italy. Fourteen of Italy's 20 regions had already declared themselves 'GMO-free'.

The fumonisin data from the trial would have been particularly embarrassing to the coalition. Many of its members had campaigned against a proposed lowering of the threshold for fumonisin from 4,000 to 2,000 parts per billion, largely because organic farming with its limited arsenal of antifungal agents would find it difficult to stay below the lower level. Indeed, in the year in which the trial took place, $>50 \%$ of the Italian maize crop exceeded the 4,000 parts per billion level of fumonisins and would have been unfit for human consumption; under the proposed lower limit, hardly any of the crop would have qualified. Ironic then that one of the leaders of the Italy/Europe Free-from-GMO campaign, former student firebrand Mario Capanna, proclaimed that "Italy is known around the world for the quality of its natural food products....It has a vast heritage of biological diversity that should not be threatened by GMO agriculture."

The media response to the November 13 press conference was markedly lukewarm. Rather than latching onto the positive data or pursuing the Ministry of Agriculture over the implications of data suppression, only a few outlets apparently found the story worthwhile. Italian newspapers La Stampa and Il Giornale did print stories and a few other newspapers ran brief coverage in their online editions. Some radio stations interviewed the researchers involved, but there was no television coverage. One respected Italian weekly, the news magazine L'Espresso, refused to run the story because its editorial policy is to "oppose GMO."

The return of the European Union presidency to Portugal last month is a reminder that having a 'knowledge-based economy' was once thought to be the only way forward for a Europe of highly paid employees and scant natural resources. But the Lisbon agenda has been diluted since Europe's leaders first signed up to it in March 2000. And it now appears that only certain types of knowledge are welcome by some of its national leaders, press and activists. 